\title{
Survey of highly specialised psychiatric services
}

\author{
J. Beasley, I. F. Brockington and A. Crisp
}

It is in the nature of Health Services that there should exist a balance between the general and the specialised; between the treatment of common conditions with generally applicable techniques and the handling of more unusual diseases. Services which require scarce skills and treat less patients who need more time are expensive. In a cost-driven situation, these skills are likely to be constrained in favour of more generally applicable, lesser standards which are cheaper.

A preoccupation with limiting cost inevitably results in moves towards economies of scale which can only be applied to conditions and treatments which occur frequently. It is inequitable and intolerable if a person with a common condition has a better prospect of treatment than someone with a less common health problem. However, doctors cannot be expected to embark on the hard road of acquiring special extra skills if there is no surety that their hard-won additional abilities will be recognised and used. Various levels of skill are required in a reasonable balance.

Internationally, there is a movement towards the development of local, community-based psychiatric services, and the closure of obsolete mental hospitals. But not all psychiatric disorders can be adequately handled by general psychiatrists and the primary health care team, some disorders require a higher level of expertise. At present there is no robust machinery for identifying national, or regional needs, and potential resources for some of the highly specialised services when these do not resonate with the aim of local purchasers and providers (Crisp, 1995).

\section{Reasons for psychiatric specialisation}

(i) The skdlls required for diagnosis and treatment are beyond the experience of general psychiatrists, as in psychiatry for deaf people, child and adolescent psychiatry, and forensic psychiatry. (ii) The treatment facility is costly and needs to be regional or sub-regional; for example, a regional secure unit, an adolescent unit, a mother and baby unit, or an in-patient service for behaviour difficulties following severe brain injury. (iii) The specialised team acts as a catalyst for service improvements, developing a focus of excellence where medical and nursing students and other professionals can best be trained and where research can be promoted. This is true of the psychotherapies, eating disorders and the addictions as well as the other specialised services mentioned above. Such centres attract good consultants and other professionals and aid the recruitment of good trainees. They can also act as a source of advice for generalists and take on the therapy of intractable cases.

The development of highly specialised psychiatric services is not usually appropriate for country towns and health districts. In larger towns and cities the public should be able to expect a proportion of the services to be more differentiated. In the main conurbations, which often act as a focus for services and training for populations as large as, or even larger than, many European nations, the aim should surely be to provide a full range of all the necessary specialities.

\section{Survey of specialised psychiatric services}

This survey examines the clinical need for, and the present provision of, the highly specialised psychiatric services, and also whether such services should be available for teaching undergraduates. All professors of psychiatry in the UK were asked to complete a simple questionnaire. Table 1 shows an analysis of the responses.

The majority of respondents were clear that highly specialised services are required. The availability of services fell far below this percetved need. Out of the services listed, six were available in less than half the areas and two more were available in less than three-quarters. Medical students were taught systematically within the highly specialised services in less than half the places from which responses were received - only cognitive and behavioural psychotherapy and eating disorders reached double figures.

Further analysis of the responses indicates that availability of highly specialised psychiatric services was overestimated because, in some cases, 
Table 1. Preliminary results of the survey of highly specialised psychiatric services. Positive responses to question $(n=36)$

\begin{tabular}{|c|c|c|c|c|}
\hline & $\begin{array}{l}\text { Should this } \\
\text { service oxist? }\end{array}$ & $\begin{array}{l}\text { Avallable in } \\
\text { your area? }\end{array}$ & $\begin{array}{l}\text { If so, are modical } \\
\text { students tought } \\
\text { oystematicelly } \\
\text { whin them? }\end{array}$ & $\begin{array}{l}\text { Important for } \\
\text { undergraducte } \\
\text { ectucation?" }\end{array}$ \\
\hline $\begin{array}{l}\text { Resistant affective disorders } \\
\text { Behavioural and cognittive } \\
\text { psychotherapy }\end{array}$ & $\begin{array}{l}27 \\
32\end{array}$ & $\begin{array}{l}13 \\
26\end{array}$ & $\begin{array}{r}7 \\
14\end{array}$ & $\begin{array}{l}14 \\
26\end{array}$ \\
\hline $\begin{array}{l}\text { Brain injury rehabilltation } \\
\text { Psychiatry for the deaf } \\
\text { Eating disorders } \\
\text { Family therapy } \\
\text { Hypochondriasis and chronic pain } \\
\text { Mother and baby psychlatry } \\
\text { Sexual disorders } \\
\text { Sleep disorders }\end{array}$ & $\begin{array}{l}32 \\
25 \\
31 \\
28 \\
21 \\
30 \\
25 \\
18\end{array}$ & $\begin{array}{r}11 \\
8 \\
23 \\
20 \\
10 \\
23 \\
17 \\
6\end{array}$ & $\begin{array}{r}3 \\
1 \\
12 \\
7 \\
6 \\
8 \\
7 \\
3\end{array}$ & $\begin{array}{l}7 \\
2 \\
26 \\
19 \\
19 \\
16 \\
20 \\
11\end{array}$ \\
\hline
\end{tabular}

"One respondent thought "all these are postgraduate topics" and no response was recelved to this question from 5 respondents

Table 2. Other highly specialised psychiatric services suggested by respondents

\begin{tabular}{ll}
\hline & Number \\
\hline Resistant psychoses or schizophrenia & 5 \\
Neurosurgery for mental disorder, epilepsy & 1 \\
and behaviour & \\
Neuropsychiatry & 1 \\
Day treatment for severe neurosis & 1 \\
Intercultural psychiatry & 1 \\
Liaison psychiatry & 1 \\
Assertive outreach & 1 \\
Forensic psychiatry & 1 \\
\hline
\end{tabular}

the responses came from professors of psychiatry from the same university or city.

A number of respondents volunteered the view that highly specialised services were also required for resistant psychoses other than affective disorders. Table 2 indicates some of the other specialised services suggested by respondents.

The results of this survey are disturbing. Psychiatric services may be regarded as warranting high priority but, in the real world, they seldom actually receive an increased proportion of resources. Expensive services, requiring the recruitment, training and retention of talented and highly skilled staff are even less attractive nowadays than they were when 'supra-district' services were planned. Local purchasers who regard themselves as chronically impoverished, in a tightening health service recession, are not going to be inclined towards expensive services for small numbers of people, which they may percetve as unaffordable luxuries.

There have always been rationalisations for neglecting mental health services. How are the essential highly specialised psychiatric services going to be developed within the present, or within a hopefully better, system?

\section{Reference}

CrisP, A. (1995) Who cares about the highly specialised services? Psychiatric Bulletin, 19, 657-659.

J. Beasley, Honorary Senior Clinical Lecturer, *I. F. Brockington, Department of Psychiatry. Queen Elizabeth Psychiatric Hospital, Mindelsohn Way, Edgbaston, Birmingham B15 2QZ; and A. Crisp, Professor of Psychiatry. University of London. (Department of Mental Health Sciences). St Georges Hospital Medical School, Tooting, London SWI 7 ORE

*Correspondence 